\title{
REDESIGN OF ENVIRONMENTAL WORK WITH ERGONOMIC INTERVENTION TO REDUCE FATIGUE AND INCREASE OUTPUT PRODUCTION
}

\author{
Sajiyo $^{1)}$, M. Adhi Prasnowo ${ }^{2)}$ \\ ${ }^{1)}$ Department of Industrial Engineering, 17 August University, Surabaya, Indonesia \\ Email : sajiyo_sastro@yahoo.co.id \\ ${ }^{2)}$ Departmen of Industrial Engineering, Maarif Hasyim Latif University, Sidoarjo, Indonesia \\ Email: prasnowoadhi@dosen.umaha.ac.id
}

\begin{abstract}
Experiments in this research carried out as follows: Tailor totaling 12 people were divided into two groups, Group "A" $=6$, group "B" $=6$. At first the group "A" work in the room of "condition sold" (the condition of the room before the ergonomics intervention) for 6 days, and the group "B" work on the room"new conditions"(conditions of the room after the intervention of ergonomics) for 6 days, then each group were closed for 1 day. Furthermore, the group "B" work on the room"old conditions" for six days and the group "A" work in the room"new conditions" for six days. To obtain research data to judge the research variables are: 1. Wind speed and light intensity, 2. Pulse Work (PW) and Pulse Rest (PR) as an indicator of the level of fatigue objectively. Collecting data subjectively exhausted with fatigue questionnaire. The results of ergonomics interventions are: (1) Increase the intensity of light becomes 354.59 Lux to 166.96 Lux, (2) Lowering the humidity from $72.35 \%$ to $57.81 \%$, ( 3) Lowering the temperature of $26.36^{\circ} \mathrm{C}$ becomes $25.48{ }^{\circ} \mathrm{C}$, (4) Improve the wind speed of 0.10 meters / sec to 0.16 meters / second, the impact of ergonomics interventions are: 1 . Lowering fatigue of work subjectively exhausted be tired, and decrease fatigue objective of becoming tired very tired, 2 . Increasing production output $24.42 \%$, from an average of 9.42 clothes / day to an average of 11.72 clothes / day. The novelty of this study is the ergonomics intervention on workplace environment, especially the workplace environment Tailor. The advantages of novelty this is the creation of collaboration and commitment of all parties, both employees as a tailor and the owner of the business as management. Besides the novelty mentioned above in this research requires a bargain (compromise) which is of mutual benefit, so as to improve the quality of interaction between the business owners and employees.
\end{abstract}

Keywords: Ergonomic, Fatigue, Output of Product

\section{INTRODUCTION}

The problem in this research are: (1) How much influence ergonomics intervention to decrease fatigue?, (2) How much influence ergonomics interventions to decrease musculoskeletal disorders?, And (3) How much influence ergonomics interventions to increase production output?. Based on the formulation of the problem in the studies above, the purpose of this study are: (1) To determine the effect of interventions ergonomics to decrease fatigue, (2) To determine the effect of interventions ergonomics to decrease musculoskeletal disorders, and (3) To determine the effect of intervention ergonomics to increase labor productivity.

\section{METHOD}

Old work space conditions: 12 meters long and 6 meters wide, there is 1 (one) door on the south, 1 (one) window on the north, and two (2) lamps, as well as in the working position Fig. 1 below this:

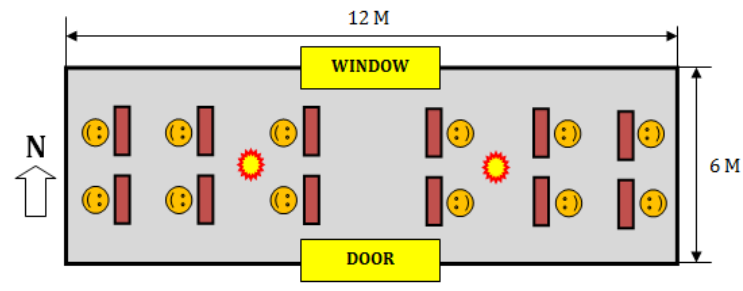

Fig.1 Old Condition Workroom

$\square$ = sewing machine position

(1:-) Tailor position

Lamp Position

In this study of ergonomics interventions include the following: (a) the installation of four (4) exhaust van; (b) the installation and setting of 4 (four) position lights; (c) setting the working position as the figure 2 below: 


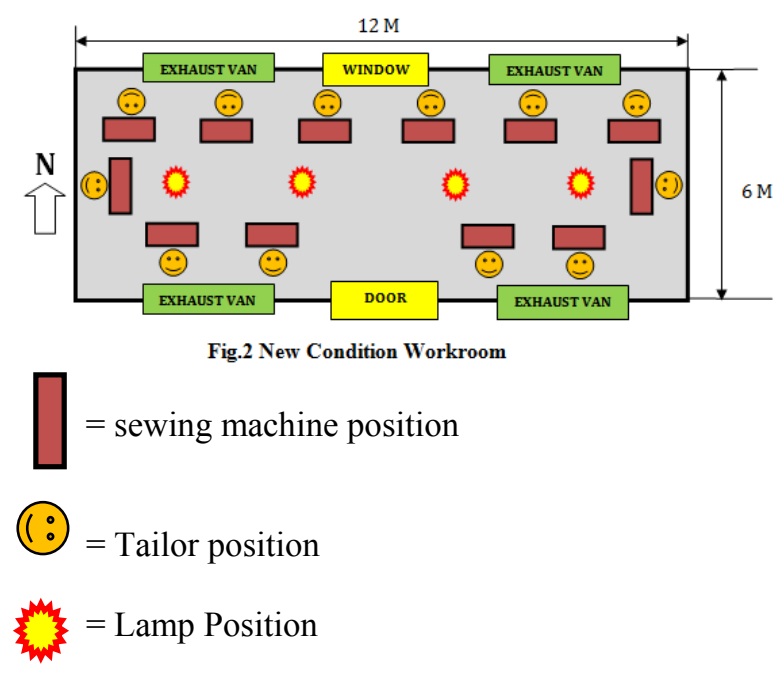

III. PROBLEM AND RESULT

A. Light Intensity

The average intensity of light on the conditions of the working space of time (before the intervention ergonomics) is $166.96 \mathrm{Lux}$, intenstas light is suitable for the low level of precision work. And the average intensity of a new light on the working conditions (after an ergonomic intervention) is 354.59 Lux, light intensity is suitable for employment with high accuracy. Whereas batik artisans work including job categories with high accuracy. Thus ergonomics interventions can improve the intensity of the light in accordance with the level of accuracy of the work.

\section{B. Humidity}

Average relative humidity at ambient conditions of work a long time (before the intervention ergonomics) is $72.35 \%$, the humidity is very high does not comply with the recommended ergonomics ie a maximum of $60 \%$. And average humidity on new working conditions (after an ergonomic intervention) is $57.81 \%$, the moisture in accordance with the recommended ergonomics is $40 \%$ $60 \%$ in the rainy season, and $40 \%-50 \%$ in the dry season.

\section{Air Temperatures}

The average temperature of the air at ambient conditions of work a long time (before the intervention ergonomics) is $26.35^{\circ} \mathrm{C}$, the air temperature is very high not in accordance with ergonomics which is the recommended maximum of $26^{\circ} \mathrm{C}$. And the average temperature on the new working conditions (after an ergonomic intervention) was $25.48^{\circ} \mathrm{C}$, the air temperature in accordance with the recommended ergonomics is $20^{\circ} \mathrm{C}$ $-24^{\circ} \mathrm{C}$ during the rainy season, and $23^{\circ} \mathrm{C}-26^{\circ} \mathrm{C}$ during the dry season.

\section{Free wind}

The average wind speed at the old work room conditions (prior to the ergonomic intervention) was 0.10 meters / second, the very low wind speed does not match what is the recommended ergonomics is minmal 0.15 meters / second. And the average wind speed in the new working conditions (after an ergonomic intervention) was
$0.16 \mathrm{~m} \mathrm{/} \mathrm{s}$ wind speed in accordance with the recommended ergonomics 0.15 meter / second during the rainy season, and 0.25 meters / sec at dry season.

\section{E. Fatigue subjective :}

The results of the data analiss subjective fatigue are: (a) the average score of subjective fatigue when working on old work room conditions (before the intervention ergonomics) is 3.22, shows workers in conditions of "extreme fatigue".The average score of subjective fatigue while working on new working conditions of the room (after intervention ergonomics) is 1.91, indicating "not tired".Means the condition of the workers is not tired while working on a new work space conditions strongly influence of ergonomics intervention.

\section{F. Pulse}

Average pulse pulse work (PW) on the condition of the working space of time (before the intervention ergonomics) is 148.00 beats / minutes showed "very heavy work load".The average pulse work (PW) on new working conditions of the room (after intervention ergonomics) is 112.88 beats / minute show "work load being",so changes in the workload of "very hard" on the condition of the workspace long been " being " the new working conditions of the room really a result of ergonomics interventions.

Average employment increased pulse rate (EIPR) on the condition of the working space of time (before the intervention ergonomics) is $57.66 \%$ showing the condition of workers "tired", and the average of employment increased pulse rate (EIPR) on new working conditions of the room (after intervention ergonomics) is $28.76 \%$ indicates that workers in a state of "no melting". So change "tired" when working on the conditions of work space of time, become"no tired" at the time worked at the room condition new work strongly as a result of ergonomics intervention

\section{G. Musculoskeletal Disorders}

Average score of musculoskeletal disorders while working at the room condition of old work (before intervention ergonomics) was 3.25 showing that the worker was "very disturbed".The average score of musculoskeletal disorders while working on new working conditions of the room (after ergonomic intervention) was 1.29 indicating "not annoyed". Change of very disturbed while working on the conditions of work space of time, and not annoyed at the condition of the new workspace, really a result of the intervention of ergonomics.

\section{H. Output Production:}

Average production output at ambient conditions of work a long time (before the intervention ergonomics) is 9 , 42 clothes / person / day, and average production output on a new working ambient conditions (after intervention ergonomics) is the clothes 11.72 / person / day. It shows that ergonomic interventions can increase the production output from an average of 9.42 clothes / person / day becoming clothes 11.72 / person / day. The average increase in production output after an ergonomic 
intervention was $24.42 \%$, an increase in the production output is actually a result of ergonomics intervention

\section{CONCLUSION}

Redesign Work Environment with Ergonomics approach can reduce fatigue of the category of "Very Tired" to "Not Tired"lowering of musculoskeletal disorders "Severely Impaired" to "Not Bothered",and can increase the production output of $49.01 \%$. To further improve the efficiency and productivity of batik makers, need to do further research on the design of sewing equipment, among others: the design table sewing machines, and a sitting chair tailor.

\section{REFERENCES}

[1]. Adiputra, 1998. Ergonomi Makro. Denpasar : Program Studi Ergonomi Fisiologi Kerja Program Pascasarjana Universitas Udayana.
[2]. Grandjean 2000. Fitting The Taqsk To he Man. A Textbook Of Ocupational Ergonomics : Taylor \& Francis Inc.

[3]. Manuaba, 1992. Pegaruh Ergonomi Terhadap Produktivitas Kerja. Makalah Semnar Perkembangan Mutakhir Perkemangan Ilmu Kedoteran. Jakarta : 30 Januari 1992

[4]. Manuaba, 2000. Ergonomi Keselamatan dan Kesehatan Kerja. Proceding Seminar Nasional Ergonomi di Surabaya. Penerbit Guna Widya.

[5]. Sajiyo, 2008. Desain Kerja Dengan Pendekatan Ergonomi Untuk Meningkatkan Produktivitas Kerja Pada Industri Rokok Di Jawa Timur. Denpasar : Disertasi Program Pascasarjana Universitas Udayana

[6]. Suma'mur, 1989. Ergonmi Untuk Produktivitas Kerja. Jakarta : Penerbit Haji Mas Agung 